\title{
Stomatognathic system screening in preschoolers and its importance for the elaboration of an intervention program in health
}

\author{
Isadora Diniz dos Santos ${ }^{1}$
} https://orcid.org/0000-0003-3325-7913

Jaqueline Carvalho dos Santos ${ }^{1}$

https://orcid.org/0000-0002-6186-7703

Aline Cabral de Oliveira ${ }^{2}$

https://orcid.org/0000-0002-8013-8653

Raphaela Barroso Guedes-Granzotti ${ }^{2}$

https://orcid.org/0000-0002-9064-439X

Sílvia Elaine Zuim de Moraes Baldrighi ${ }^{3}$

https://orcid.org/0000-0002-3107-5019

Carla Patrícia Hernandez Alves Ribeiro César²

https://orcid.org/0000-0002-9439-9352

\section{ABSTRACT}

Purpose: to describe the results obtained in the stomatognathic system screening applied in preschoolers of the public and private school systems.

Methods: a cross-sectional, observational study randomly which selected four preschools linked to the Diretoria Regional de Educação. Two municipalities were drawn, and the educational institutions located in the city Center were selected. After submission of the proposal to the secretaries, managers and family members, the consent was granted for the screening involving face structures, muscle tonus, teeth, occlusion, mobility, speech, breathing, chewing and swallowing, by means of a tested and standardized protocol for evaluation of the stomatognathic system in a synthesized way. The results were submitted to descriptive statistical analysis and the chi-square test, with a significance level of $5 \%$.

Results: a total of 218 preschoolers, aged between two and six years old, participated in the study. Most of the participants, regardless of the institution attended, presented normality of the aspects surveyed. However, when comparing preschool children results among the institutions, there were significant differences for facial symmetry, speech, swallowing (for students in public schools), structural aspects and muscle tonus (private schools).

Conclusion: the results obtained allowed the differentiated planning of health promotion and preventive actions of orofacial myofunctional disorders for preschoolers of distinct institutional systems, determining the importance of epidemiological surveys in health promotion spaces.

Keywords: Speech, Language and Hearing Sciences; Primary Health Care; Stomatognathic System 


\section{INTRODUCTION}

The intersectoral dialogue between Health and Education becomes essential for the implementation of projects to transform educational institutions into a space for health promotion ${ }^{1}$.

Regarding Speech, Language and Hearing Sciences, this work is based on respect and co-responsibility of actions in a network with other health professionals, managers, community and other sectors, therefore, all are motivated for such an attempt ${ }^{2}$, requiring periodic planning, execution and strategic alignment, making the task more complex ${ }^{3}$.

Among the aspects used to transform the health reality of specific population groups is the use of epidemiological data for the determination of priorities, resources and programmatic orientation, as described in the seventh article of the Sistema Único de Saúde Law $^{4}$.

A national study evidenced high rates of stomatognathic system deviations/alterations in preschool children $(85.89 \%)^{3}$ whereas, in international studies, they found percentages of $37.65 \%{ }^{5}$ and $3.4 \%^{6}$. Changes in this phase of life reveal the need for attention of health professionals to propose interdisciplinary preventive and educational actions in partnership with the Health and Education Secretariats of their municipalities.

In addition, the knowledge of health professionals that changes in the structural aspects of the face can cause several symptoms that impair breathing and sleep $^{7}$ and, consequently, learning ${ }^{8}$, is important for early interdisciplinary intervention.

Thus, the objectives of this study were to describe the results obtained in the screening of the stomatognathic system of preschoolers in public and private teaching schools, as well as to verify the importance of this screening for the elaboration of an intervention program.

\section{METHODS}

Study approved by the Research Ethics Committee of the Federal University of Sergipe (CAAE: 0060.0.214.000-09). It was an observational, transversal and descriptive study performed in preschool children in the state of Sergipe. According to data from the Brazilian Institute of Geography and Statistics, the estimated population of Sergipe is 2,265,779 inhabitants, distributed in 75 municipalities ${ }^{9}$.

A random choice (through draws) of four preschools in the interior of the state (two public and two private schools), located in the central region of the municipality, was carried out in institutions linked to the Diretoria Regional de Educação - Regional Education Board (DRE2), comprising six municipalities (Lagarto, Salgado, Boquim, Poço Verde, Simão Dias and Riachão do Dantas), with two being drawn: Lagarto and Salgado.

These municipalities are located in the Center-South of the state of Sergipe and are $23.8 \mathrm{~km}$ apart. The economic activity of these municipalities is predominantly agricultural ${ }^{9}$.

The screening proposal was presented to the Secretariat of Education of the Municipalities, the administrators of educational institutions and the guardians of the preschoolers.

Were included in this study children between two and six years old, with the authorization of their parents and educators to participate in the screening. Children who were submitted to Speech, Language and Hearing Sciences, orthodontic or facial orthopedic treatment, with a positive history of facial and pharyngeal surgeries, with craniofacial malformations, neurological, genetic, intellectual and auditory alterations; as well as those who had a cold or the flu on the day of the evaluation were excluded.

The sample groups were selected by convenience, since pre-school managers needed to accept the proposal. To minimize the bias of this choice, we chose to set the groups without other variables that interfered in the analysis, such as the number of preschoolers and the gender of the participants. However, it was not possible to divide groups equally by age, with a greater number of children aged between four and five years old, age in which children tend to collaborate more.

Therefore, smaller children are usually considered as challenges at the time of research and spend more time in order to establish a bond of trust between the researcher and the subject. Thus, even if the sampling group of two-year-olds was considered small (six children), it was decided to remain with this age group, in order to establish activities that were also directed to it.

Thus, after the application of the aforementioned criteria, screening was performed in a room provided by the institutions (with good lighting, ventilation, and minimal noise interference), through interviews with parents and screening of the stomatognathic system.

The data collection instrument was divided into two parts, the first one containing the identification data and socioeconomic indicators, and the second, the 
screening of the stomatognathic system, using the $\mathrm{MBGR}^{10}$ synthesized protocol. Were used a Glatzel mirror, to check expiratory nasal airflow, water (offered in a $200 \mathrm{ml}$ transparent plastic glass) and salt bread (2 $\mathrm{cm}$ slice) for swallowing. The bread was also used for chewing screening.

All speech productions were recorded on a camera in the video function, using the Sony Cyber-Shot digital camera (7.2 megapixels), DSC P200 model. The children were photographed in the positions: forward and profile ${ }^{11}$. The screenings had a duration of 20 minutes, and the results were classified as "normal", when the item evaluated corresponded to what was expected for the standard of normality for age (with zero scores in the MBGR protocol) $)^{10}$ and "altered" if it presented the characteristics described below (with score $\geq 1$ in the protocol used) ${ }^{10}$ :

- Structural aspects: facial asymmetry, open or parted lips with accumulation of saliva or drool; mucosa of cheeks or tongue with dental marks and / or wounds; short and / or anterior tongue frenulum; bony palate with increased or reduced depth and / or width; asymmetrical muscular palate, with long or short extension; bifid and / or diverted uvula; hypertrophied palatine tonsils; bad dental and gingival conservation; presence of open bite, cross or midline deviation (all checked by visual inspection and flashlight aid, when necessary);

- Mobility: non-performance or difficulties for lip (bursting, bulging, retracting and alternating between protrusion and retraction), tongue (protrusion, alternating between protrusion and retraction, lateralizing, popping and vibrating), cheeks (inflate), muscle palate (repeated emission of the / a /) and jaw (opening, closing and laterality) mobility.

- Muscle Tonus: increased or decreased (screened by palpation of the triangular orofacial muscles) and

- Oral functions: Respiratory mode altered by visualization of open lips, difficulty in maintenance of sealed lips for two minutes or more, and asymmetric expiratory nasal airflow after nostrils cleaning (screened by using a millimeter mirror below the nostrils during expiration); chewing with lateral incision, inefficient grinding, simultaneous unilateral or bilateral chronic pattern, decreased speed and presence of atypical muscular contractions (analyzed with the French bread offer); swallowing with visible tongue interposition, lower lip in contact with upper incisors, lack of fluid restraint, increased fluid volume, presence of noise, incoordination between breathing and swallowing and / or the presence of atypical muscle contractions (verified with clear plastic cup with water supply); speech with presence of unexpected omissions for the age group and distortions of the speech sounds (observed by spontaneous talk and MBGR protocol figures) ${ }^{10}$.

From the obtained results, the family members received individual feedbacks and were guided on the necessary behaviors; educators and family members received educational material containing information on various topics, and the managers participated in a meeting to discuss necessary actions for the reduction of existing myofunctional orofacial disorders.

The results obtained were typed in an Excel spreadsheet software. Descriptive statistical analysis was used and Pearson's Chi-Square test was used to compare the groups, considering a significance level of $5 \%$.

\section{RESULTS}

There were 108 preschoolers from two public and 110 from two private institutions (total: 218 children).

As to sex, 101 were boys ( 51 from the public and 50 from the private one, corresponding to $46.33 \%$ of the sample) and 117 girls (57 from the public and 60 from the private one, $53.67 \%$ from the sample), with no statistical differences -were revealed in the distribution between the type of institution attended and the sex of the participants $(p=0.892)$.

Regarding socioeconomic and cultural conditions, it was observed that the majority (84.9\%) had a family income of up to two minimum wages. The difference between the socioeconomic and cultural profile was only related to the parents' schooling, and in the public institution, the majority $(n=71,81.6 \%)$ did not have a complete Elementary School, whereas, in the private institution, 63 (63.77\%) presented complete Elementary School and 36 (36.23\%) incomplete High School.

The age group of the sample consisted of preschoolers from two to six years of age (mean: 4.12 \pm 0.95 ), with a statistically significant difference for the ages of four and five years ( $p<0.001)$, evidenced by the higher number of preschoolers in this age group, but without differences among educational institutions. In general, changes in the stomatognathic system were found in 94 preschool children (43.12\%), regardless of the institutions attended.

In the orofacial structural aspects, statistically significant differences were observed in facial symmetry, 
with more evident alterations in public institutions $(p=$ 0.018 ); in the cheeks, pharyngeal tonsils, hard palate and dental occlusion, with a greater number of alterations in the private institutions $(p<0.001)$. In the other structures (lips, tongue, and teeth), no statistically significant differences were observed (Table 1).

There was no difference between the investigated institutions (Table 2) regarding the mobility of the lips, tongue, cheeks, jaw and palatine veil.
Concerning the muscle tonus of the orofacial structures, it was possible to observe that the preschoolers of the private institutions had a higher occurrence of changes, with statistically significant results (Table 3).

In the oral functions, the tests that revealed statistical differences were those of swallowing and speech, with worse results in the preschoolers of the public school system (Table 4).

Table 1. Characterization of the structural aspects screened in preschool students of the participating institutions

\begin{tabular}{|c|c|c|c|c|c|}
\hline \multirow{3}{*}{ Structural Aspects / Institutions } & \multicolumn{2}{|c|}{ Public } & \multicolumn{2}{|c|}{ Private } & \multirow{3}{*}{ Chi-square Test } \\
\hline & Normal & Altered & Normal & Altered & \\
\hline & $\mathrm{N}(\%)$ & $\mathrm{N}(\%)$ & $\mathrm{N}(\%)$ & $\mathbf{N}(\%)$ & \\
\hline Facial Symmetry & $100(45.9 \%)$ & $8(3.6 \%)$ & $109(50 \%)$ & $1(0.5 \%)$ & $p=0.018^{*}$ \\
\hline Lips & $95(43.6 \%)$ & $13(6 \%)$ & 88 (40.4\%) & $22(10 \%)$ & $p=0.140$ \\
\hline Cheeks & 97 (44.7\%) & 11 (5.1\%) & 73 (33.6\%) & 36 (16.6\%) & $p<0.001^{*}$ \\
\hline Tongue & $83(39.4 \%)$ & $22(10.1 \%)$ & $88(40.4 \%)$ & $22(10.1 \%)$ & $p=1.000$ \\
\hline Palate & $94(43.1 \%)$ & $14(6.4 \%)$ & $69(31.7 \%)$ & $41(18.8 \%)$ & $p<0.001^{*}$ \\
\hline Pharyngeal Tonsils & $99(45.6 \%)$ & $9(4.1 \%)$ & $86(39.4 \%)$ & $24(11 \%)$ & $p=0.008^{*}$ \\
\hline Teeth & $89(40.8 \%)$ & $19(8.8 \%)$ & $99(45.4 \%)$ & $11(5 \%)$ & $p=0.118$ \\
\hline Occlusion & 74 (33.9\%) & 34 (15.6\%) & 47 (21.6\%) & 63 (28.9\%) & $p<0.001^{*}$ \\
\hline
\end{tabular}

Table 2. Comparison of the mobility of orofacial structures of preschoolers from public and private institutions

\begin{tabular}{|c|c|c|c|c|c|c|c|c|c|c|c|c|c|c|c|c|c|c|c|c|}
\hline \multirow{4}{*}{ Institutions } & \multicolumn{20}{|c|}{ Mobility } \\
\hline & \multicolumn{4}{|c|}{ Lips } & \multicolumn{4}{|c|}{ Tongue } & \multicolumn{4}{|c|}{ Cheeks } & \multicolumn{4}{|c|}{ Palatine Veil } & \multicolumn{4}{|c|}{ Jaw } \\
\hline & \multicolumn{2}{|c|}{ Normal } & \multicolumn{2}{|c|}{ Altered } & \multicolumn{2}{|c|}{ Normal } & \multicolumn{2}{|c|}{ Altered } & \multicolumn{2}{|c|}{ Normal } & \multicolumn{2}{|c|}{ Altered } & \multicolumn{2}{|c|}{ Normal } & \multicolumn{2}{|c|}{ Altered } & \multicolumn{2}{|c|}{ Normal } & \multicolumn{2}{|c|}{ Altered } \\
\hline & $\mathrm{N}$ & $\%$ & $\mathbf{N}$ & $\%$ & $\mathbf{N}$ & $\%$ & $\mathbf{N}$ & $\%$ & $\mathrm{~N}$ & $\%$ & $\mathrm{~N}$ & $\%$ & $\mathrm{~N}$ & $\%$ & $\mathbf{N}$ & $\%$ & $\mathrm{~N}$ & $\%$ & $\mathbf{N}$ & $\%$ \\
\hline Public & 59 & 27.1 & 49 & 22.5 & 36 & 16.6 & 72 & 33.0 & 58 & 26.7 & 50 & 23.0 & 97 & 44.5 & 11 & 5.0 & 105 & 48.1 & 3 & 1.4 \\
\hline Private & 74 & 33.9 & 36 & 16.5 & 45 & 20.6 & 65 & 29.8 & 69 & 31.8 & 40 & 18.5 & 101 & 46.3 & 9 & 4.2 & 107 & 49.1 & 3 & 1.4 \\
\hline Total & 133 & 61 & 85 & 39 & 81 & 37.2 & 137 & 62.8 & 127 & 58.5 & 90 & 41.5 & 198 & 90.8 & 20 & 9.2 & 212 & 97.2 & 6 & 2.8 \\
\hline $\begin{array}{c}\text { Chi-Square } \\
\text { Test }\end{array}$ & \multicolumn{4}{|c|}{$p=0.71$} & \multicolumn{4}{|c|}{$p=0.265$} & \multicolumn{4}{|c|}{$p=0.169$} & \multicolumn{4}{|c|}{$p=0.646$} & \multicolumn{4}{|c|}{$p=1.00$} \\
\hline
\end{tabular}

Table 3. Comparison of the muscle tonus of the orofacial structures of the preschoolers of public and private institutions

\begin{tabular}{cccccc}
\hline & \multicolumn{3}{c}{ Muscle tonus } \\
\cline { 2 - 6 } Institutions & Normal & N & N & Altered \\
\cline { 2 - 5 } & 99 & 45.4 & 9 & 4.1 \\
Public & 76 & 34.9 & 34 & 15.6 \\
Private & 175 & 80.3 & & 43 & 19.7 \\
Total & & & ${ }^{*} \mathrm{p}<0.001$ & & \\
Chi-Square Test & & & & \\
\hline
\end{tabular}


Table 4. Comparison of the oral functions of preschoolers from public and private institutions

\begin{tabular}{|c|c|c|c|c|c|c|c|c|c|c|c|c|c|c|c|c|}
\hline \multirow{4}{*}{ Institutions } & \multicolumn{16}{|c|}{ Oral Functions } \\
\hline & \multicolumn{4}{|c|}{ Breathing } & \multicolumn{4}{|c|}{ Chewing } & \multicolumn{4}{|c|}{ Swallowing } & \multicolumn{4}{|c|}{ Speech } \\
\hline & \multicolumn{2}{|c|}{ Normal } & \multicolumn{2}{|c|}{ Altered } & \multicolumn{2}{|c|}{ Normal } & \multicolumn{2}{|c|}{ Altered } & \multicolumn{2}{|c|}{ Normal } & \multicolumn{2}{|c|}{ Altered } & \multicolumn{2}{|c|}{ Normal } & \multicolumn{2}{|c|}{ Altered } \\
\hline & $N$ & $\%$ & $\mathbf{N}$ & $\%$ & $N$ & $\%$ & $\mathbf{N}$ & $\%$ & $N$ & $\%$ & $N$ & $\%$ & $\mathrm{~N}$ & $\%$ & $\mathrm{~N}$ & $\%$ \\
\hline Public & 93 & 42.6 & 15 & 6.9 & 70 & 32 & 38 & 17.4 & 99 & 45.5 & 9 & 4.1 & 29 & 13.3 & 79 & 36.3 \\
\hline Private & 98 & 45.0 & 12 & 5.5 & 65 & 30 & 45 & 20.6 & 108 & 49.5 & 2 & 0.9 & 62 & 28.4 & 48 & 22.0 \\
\hline Total & 191 & 87.6 & 27 & 12.4 & 135 & 61.9 & 83 & 38.0 & 207 & 95.0 & 11 & 5.0 & 91 & 41.7 & 127 & 58.3 \\
\hline Chi-Square Tes & \multicolumn{4}{|c|}{$p=0.543$} & \multicolumn{4}{|c|}{$p=0.405$} & \multicolumn{4}{|c|}{${ }^{*} p=0.033$} & \multicolumn{4}{|c|}{${ }^{*} p<0.01$} \\
\hline
\end{tabular}

\section{DISCUSSION}

Ideally, public health policies should be organized and guided by evidence-based practice and analysis of the health status of population groups ${ }^{12}$.

Thus, the situational analysis of the health of pre-school children in the participating municipalities was carried out, so that, it was possible to elaborate a health program that would meet the locoregional needs. For this reason, two distinct realities were elected: public and private schools of education. As the socioeconomic stratum can differentiate the members of these networks, this condition was analyzed, by the socioeconomic stratum, this condition was analyzed, being verified that the sample was not differentiated by family income, housing, and work. There was a difference in the level of education of the parents, and, in public education, the majority did not present complete Elementary School. However, the private ones presented it as complete and an incomplete High School. No justification was found in the literature to explain why subjects with the same socioeconomic stratum presented different degrees of education. It is hypothesized that the incomes were equated between the groups under the monetary transfer made possible by the Bolsa Familia Program, and a detailed study of the particularities of the participating families was necessary.

It is known, however, that the low socioeconomic family stratum and schooling of the parents are social determinants that can negatively influence children's health ${ }^{13}$, justifying the performance of research that verifies the communication, and, especially those related to the stomatognathic system, responsible for oral functions such as speech, chewing, swallowing, breathing, and sucking.

Regarding the screenings of orofacial structural aspects, facial symmetry, cheek, palate, and occlusion, alterations were found. According to the literature ${ }^{14}$, the factors that cause facial asymmetry are functional, skeletal, dental or a combination of these. Thus, the evaluation would be necessary to elucidate the reasons that led the public-school preschoolers to present facial asymmetry, being, this, a limitation of this study.

Researchers ${ }^{15}$ observed that $81 \%$ of the structural changes in children concerned soft tissue changes, such as inadequate resting posture of the lips and tongue; inadequate mobility and tonicity of cheeks, lips and tongue and, regarding the alterations in hard structures, it was less frequent (19\%), being highlighted the ones related to the type of bite (open and crossed) and the morphological alteration of the palate (ogival).

Also regarding the structural orofacial aspects, cheek (presence of dental marks, Alba line or wounds), palate (depth, hard palate width, and symmetry and soft palate extension) and occlusion (horizontal, vertical or transverse) alterations were observed. Such changes suggest a more detailed evaluation and preventive and promotive actions of Dentistry. The ideal would be to carry out interdisciplinary and collaborative interventions, in order to achieve interprofessional education, a practice developed by the World Health Organization ${ }^{16}$, to improve global health outcomes.

A possible explanation for the above-mentioned orofacial structural alterations may be the fact that, usually, the signs of the deleterious oral habit of dental tightening or bruxism can be verified by dental marks on the lateral borders of the tongue, presence of Alba line or wounds on the mucosa of the cheeks, as observed in the pre-school children investigated, and may also cause changes in cheek and bite muscle tonus alimentary functions and breathing ${ }^{17}$.

Thus, awareness of this habit and early intervention with preschoolers and their relatives can minimize or cure possible changes in the performance of stomatognathic functions. Therefore, the ideal would be the organization of interprofessional health teams, 
including the Pediatrician, the Speech Therapist, the Odontopediatrician and the Psychologist.

Occlusal and dental alterations, even if they did not differ between groups and with percentages that indicated normality for the majority of preschoolers, suggest a more detailed evaluation, with longitudinal follow-up of these preschoolers, and preventive and promotive actions of Dentistry. These data resulted in a discussion with both the university professors of the respective undergraduate course, in order to follow up such children; as well as with the families and the managers of the institutions, for the adoption of daily prophylactic measures and the referral to the professionals of the health network. It would be ideal, therefore, the implementation of interdisciplinary and collaborative interventions, so that the interprofessional education, a practice idealized by the World Health Organization ${ }^{16}$, could be achieved for the improvement of global health outcomes.

Other interesting data were the structural alteration in hard palate, that is, of increased depth and reduced width, as well as in pharyngeal tonsils, with hypertrophy. When the bony palate is higher, it can invade the internal space of the nasal fossae, causing a mechanical obstacle and a modification of the respiratory mode from nasal to oral ${ }^{18}$. In addition, the use of the nurse bottle for a prolonged period can cause a decrease of the mandibular action, causing the tongue to press the bottle nipple against the palate, which can lead to ogival palate ${ }^{19}$. However, the presence of deleterious oral habits was not investigated, representing a limitation of this study.

Increased size and volume of pharyngeal tonsils found in preschoolers attending private schools may be predisposed to sleep disorders, such as sleep apnea syndrome (OSAS), although other causes may lead to OSAS, requiring larger investigations ${ }^{20}$. The preschool children who presented enlargement of the pharyngeal tonsils were referred for otorhinolaryngological evaluation and conduction.

When the tonsils appear with increased volume, there is the adaptation of the positioning of the tongue in the intraoral cavity. Therefore, the tongue adopts a lowered and forwarded posture and, consequently, comes into contact with the dental occlusal surfaces, being able to generate malocclusion and adaptations of oral functions, such as chewing, swallowing and speech.

There are several consequences for the stomatognathic system in the presence of malocclusions, such as adaptation in the labial space and chewing functions (with possibility of modification of the food incision, the pattern, rhythm and efficiency of grinding), deglutition (atypically produced) and speech (with articulatory distortion and inaccuracy) - all due to the adaptation of the tongue positioning when performing different actions ${ }^{21}$.

Considering that almost half of the sample presented occlusal alterations, the insertion of preventive measures and the referral to Pediatric Dentistry were performed. A study ${ }^{22}$ evidenced a high prevalence of malocclusion in preschool children, with more frequent findings of anterior open bite associated with canine and molar crossing, corroborating the findings obtained in this study.

No differences were found among preschoolers related to the mobility of phonoarticulatory organs, with the exception of the difference in the acquisition of tongue and cheek mobility between the ages of preschool children, being verified more difficulty among the smaller preschool children when compared to the older ones. A study ${ }^{3}$ reported similar results, adding that skeletal muscle mobility tends to improve with advancing age, with mandibular movements performed smoothly from the age of three, followed by the lips at four years old and the tongue-and-mouth movements at five years old.

Regarding the muscle tonus of the orofacial triad structures, the preschoolers of the private institutions had a higher occurrence of changes, with statistically significant results. Some factors may influence the muscle tonus of the orofacial musculature, such as altered respiratory mode, occlusal conditions ${ }^{23}$, and praxis, and there seems to be an association between muscle tonus and non-verbal praxis movements of the tongue and speech changes ${ }^{24}$. Malocclusion, as observed in the results obtained, was found more frequently in preschoolers of private schools than in public schools, and may justify higher tonus changes, since oral breathing did not reveal differences between groups.

The oral functions that revealed statistically significant differences among the preschoolers were swallowing (atypical) and speech (especially phonetic disturbances), which were worse in preschoolers of the public school system. The possible causes of atypical swallowing are finger/tongue sucking, bottle feeding, oral breathing ${ }^{25}$ and malocclusion, and the greater the severity of the condition, the higher the likelihood of association with myofunctional orofacial disorders ${ }^{26}$. 
Atypical swallowing may further aggravate malocclusion and lead to phonetic disturbances in speech.

Regarding speech, $79 \%$ of preschool children presented alterations, and this percentage was considered a high index of liquid simplification, confirming the literature ${ }^{24}$, although the age group of the study cited ${ }^{24}$ regarded preschoolers between four and five years old and the one of this study included preschoolers up to six years of age. In addition to the above, there was a strong association between the speech disorders of preschool children and the low schooling of the relatives of public school attendants. From this perspective, it can be inferred that the higher the schooling, the greater the possibility of using the cultured norm spoken in the family and, therefore, it will be learned by the children.

It is known that speech disorders can lead to various impairments, such as those in literacy (depending on the nature of the disorder), social-interactions and emotions. A research ${ }^{27}$ evidenced that children who suffer from bullying due to some speech disorder seek help from speech therapists and that, although such professionals have been trained to act in this environment, they have declared themselves unprepared for it, and bullying is very frequent in schools for the reason presented. The question asked is: Do Brazilian speech therapists know how to deal with bullying? And what about professionals who work with preschoolers, such as pediatricians, nurses and others? This is a topic that deserves greater attention from professionals in the field and from researches that can highlight the reality and the measures that must be taken. After all, according to the literature ${ }^{28}$, bullying can be controlled early, when detected and conducted appropriately by the family, school, and society, in a non-isolated way.

From the results obtained in the screenings, intervention programs were designed for each participating institution, in order to cover the greater difficulties of their preschoolers. The duration of the programs was one year and the activities developed were weekly, lasting one hour. Thus, thematic workshops were held in the classroom, with activities stimulating the mobility of the phonoarticulatory organs using music; awareness of chewing and swallowing through dramatization, using puppets and videos; working with phonological awareness in group dynamics, tactile-kinesthetic, visual and auditory proprioceptive clues; with workshops on tales about dental hygiene, deleterious oral habits and bullying. Educational materials with definitions, etiological factors, signs and symptoms, care and behaviors against oral breathing, malocclusion, speech disorders, cleft lip and palate and didactic material for educators, regarding the acquisition and development of speech, were made available. There was also a weekly evaluation of the program by the preschoolers (with ideograms symbolizing joy - indicating satisfaction, regular - ideogram symbolizing neutral face, and sadness - indicating dissatisfaction), and educators (individual interview); as well as bimonthly meetings with family members (in meetings for this purpose). The referrals were made to different health professionals (otorhinolaryngologists, dental pediatricians, nutritionists and speech therapists). The evaluations showed satisfaction with the programs implemented by the majority of participants.

Thus, it is possible to affirm that integrated actions of the different health professionals are necessary to minimize these diseases, which can interfere in the social functions of communication and feeding, as well as in facial aesthetics.

\section{CONCLUSION}

Most of the preschool children presented alterations in the stomatognathic system, and the children of private institutions had more changes regarding muscle tonus, structural aspects of cheeks, palate and occlusion. Children from public institutions presented more alterations in facial symmetry, swallowing and speech, justifying the importance of screening for epidemiological surveys, as well as for the implementation of preventive and interdisciplinary actions of orofacial myofunctional disorders, in the context of early childhood education institutions.

\section{REFERENCES}

1. Santos Silva C, Andrade Bodstein RC. A theoretical framework on intersectoral practice in School Health Promotion. Ciênc. Saúde Colet. [serial on the Internet] 2016 Jan [cited 2017 Nov 24]; 21(6):1777-88. Disponível em: https://www.scielosp. org/pdf/csc/v21n6/1413-8123-csc-21-06-1777.pdf.

2. César CP, Santos CS, Andrade JS, Sordi C. Promoção da saúde e fonoaudiologia: possibilidades de atuação. In: Paranhos LR, César CPHAR, Sordi C (orgs). Coletâneas em Saúde. São José dos Pinhais: Plena, 2016. p. 71-80.

3. Santos JC, Guedes-Granzotti RB, Barreto ACO, Oliveira CC, Silva K, Baldrighi SEZM et al. Small 
citizen project: health promotion and prevention of child nutrition and orofacial motricity disorders. Distúrb Comun. [serial on the Internet] 2016 Mar [cited 2017 Nov 24]; 28(1):151-61. Available from: http://revistas.pucsp.br/index.php/dic/article/ view/23939/19303.

4. Brasil. Conselho Nacional de Saúde. Lei 8080 , de 19 de setembro de 1990. Brasília: CNS; 1990 [cited 2017 Nov 24]. Available from: http://conselho. saude.gov.br/legislacao/lei8080_190990.htm.

5. Rajchanovska D, Zaifirova IB. The impact of demographic and socio-economic conditions on the prevalence of speech disorders in preschool children in Bitola. Srpski arhiv za celokupno lekarstvo. [serial on the Internet]. 2015 Mar-Apr [cited 2017 Nov 24]; 143(3-4):169-73. Available from: http://citeseerx.ist.psu.edu/viewdoc/downloa $\mathrm{d}$ ?doi=10.1.1.942.921\&rep= rep1\&type = pdf.

6. Eadie P, Morgan A, Ukoumunne OC, Ttofari Eecen K, Wake M, Reilly S. Speech sound disorder at 4 years: prevalence, comorbidities, and predictors in a community cohort of children. Dev. med. child. neurol. [serial on the Internet] 2015 Jun [cited 2017 Nov 24]; 57(6):578-84. Available from: http:// onlinelibrary.wiley.com/doi/10.1111/dmcn.12635/ epdf.

7. Al Ali A, Richmond S, Popat H, Playle R, Pickles $\mathrm{T}$, Zhurov Alet al. The influence of snoring, mouth breathing and apnoea on facial morphology in late childhood: a three-dimensional study. BMJ open. [serial on the Internet] 2015 Sep [cited $2017 \mathrm{Nov}$ 24]; 5(9):e009027. Available from: http://bmjopen. bmj.com/content/bmjopen/5/9/e009027.full.pdf.

8. Ribeiro GC, Santos ID, Santos AC, Paranhos LR, César CPHAR. Influence of the breathing pattern on the learning process: a systematic review of literature. Braz. j. otorhinolaryngol. [serial on the Internet] 2016 Jul-Ago [cited 2017 Nov 24]; 82(4):466-78. Available from: http://www.scielo.br/ pdf/bjorl/v82n4/pt_1808-8694-bjorl-82-04-00466. pdf.

9. Brasil. Censo Demográfico 2010. Características da população e da educação. Rio de Janeiro: IBGE; 2011 [cited 2016 Mar 28]. Available from: http:// www.ibge.gov.br/home/estatistica/populacao/ censo2010/resultados_preliminares_amostra/ notas_resultados_preliminares_amostra.pdf.

10. Genaro KF, Berretin-Felix G, Rehder MIBC, Marchesan IQ. Avaliação miofuncional orofacial - protocolo MBGR. Rev. CEFAC [serial on the Internet] 2009 Abr-Jun [cited 2016 Mar 29]; 11(2):237-55. Available from:http://www. scielo.br/scielo.php?script =sci_arttext\& $\mathrm{pid}=\mathrm{S} 1516-18462009000200009$.

11. Silveira MC, Sígolo C, Quintal M, Sakano E, Tessitore A. Proposta de documentação fotográfica em motricidade oral. Rev. CEFAC. [serial on the Internet] 2006 Out-Dez [cited 2016 Mar 29]; 8(4):485-92. Available from: http://www.scielo.br/ $\mathrm{pdf} / \mathrm{rcefac} / \mathrm{v} 8 \mathrm{n} 4 / \mathrm{v} 8 \mathrm{n} 4 \mathrm{a009}$.pdf.

12. Guimarães RM, Meira KC, Paz EP, Dutra VG, Campos CE. Os desafios para a formulação, implantação e implementação da Política Nacional de Vigilância em Saúde. Ciênc. Saúde Colet. [serial on the Internet] 2017 Maio [cited 2017 Nov 27]; 22(5):1407-16. Available from: http://www.redalyc. org/pdf/630/63050935003.pdf.

13. Assis SG, Avanci JQ, Oliveira RVC. Socioeconomic inequalities and child mental health. Rev Saúde Pública. [serial on the Internet] 2009 Jun. [cited 2016 Mar 29]; 43(1):92-100. Available from: http://www.scielo.br/scielo. php? script $=$ sci_nlinks \& $\mathrm{ref}=000096 \& \mathrm{pid}=$ S0102$7972201300030000300006 \&$ lng $=$ pt.

14. Procaci MIMA, Ramalho SA. Crescimento assimétrico da face: atividade muscular e implicações oclusais. Rev. dent. Press Ortodon. Ortopedi. Facial 2002;7(6):87-93.

15. Czlusniak GR, Carvalho FC, Oliveira JP. Alterações de motricidade orofacial e hábitos nocivos orais em crianças de 5 a 7 anos de idade: implicações para intervenções fonoaudiológicas em âmbito escolar. UEPG CiBiol Saúde. [serial on the Internet] 2008 Mar [cited 2016 Mar 29]; 14:29-39. Available from: http://177.101.17.124/index.php/biologica/article/ view/480/481.

16. Organização Mundial da Saúde. Marco para ação em educação interprofissional e prática colaborativa. Genebra: OMS; 2010 [cited 2017 Nov 27]. Available from: http://new.paho.org/bra/images/stories/ documentos/marco_para_acao.pdf\%20.

17. Simões-Zenari M, Bitar ML. Fatores associados ao bruxismo em crianças de 4 a 6 anos. Pró-Fono R. Atual. Cientif. [serial on the Internet] 2010 Out-Dez [cited 2016 Apr 05]; 22(4):465-72. Available from: http://www.scielo.br/scielo.php? script $=$ sci $_{\text {_ }}$ arttext\&pid $=$ S0104-56872010000400018\&lng $=$ en.

18. Carvalho GD. Estruturas estomatognáticas alteradas na síndrome do respirador bucal. In Carvalho GD (org). S.O.S. Respirador bucal: uma 
visão funcional e clínica da amamentação. São Paulo: Lovise; 2003. p. 65-100.

19. Cotrim LC, Venancio SI, Escuder MML. Uso de chupeta e amamentação em crianças menores de quatro meses no estado de São Paulo. Rev. bras. saúde matern. infant. [serial on the Internet], 2002 Set-Dez [cited 2016 Mar 29]; 3(2):245-52. Available from: http://www.scielo.br/pdf/rbsmi/v2n3/17094.pdf.

20. Sólyom R, Csiszér IR, Neagos A. Tonsillar hypertrophy implications in sleep disorders in adults and children. Rom J Morphol Embryol. [serial on the Internet], 2014 Jan [cited $2017 \mathrm{Nov}$ 27];55(2 Suppl):603-6. Available from: http://www. rjme.ro/RJME/resources/files/551214603606.pdf.

21. Vieira D, Carreira IP, Silva MR, Andrade JS, Santos FFD, César CPHAR. A interferência das más oclusões nas funções estomatognáticas. In: César CPHAR, Paranhos LR, Sordi C (eds). Coletâneas em saúde. São José dos Pinhais: Plena; 2017. p. 65-76.

22. Sadakyio CA, Degan VV, Pignataro Neto G, Puppin Rontani RM. Prevalência de má oclusão em pré-escolares de Piracicaba-SP. Braz. dent. sci. [serial on the Internet], 2004 Abr-Jun [cited 2016 Apr 26]; 7(2):92-9. Available from: http://dx.doi. org/10.14295/bds.2004.v7i2.493.

23. Marchesan IQ. Avaliando e tratando o sistema estomatognático. In: Lopes Filho O (ed). Tratado de fonoaudiologia. São Paulo: Roca; 1997. p. 763-80.

24. Farias SR, De Ávila CRB, Vieira MM. Relação entre fala, tônus e praxia não-verbal do sistema estomatognático em pré-escolares. Pró-Fono $R$ Atual. Cientif. [serial on the Internet] 2006 Set-Dez [cited 2016 Mar 29]; 18(3):267-76. Available from: http://www.scielo.br/pdf/pfono/v18n3/a06v18n3.pdf.

25. Machado Junior AJ, Crespo AN. Avaliação cefalométrica do espaço orofaríngeo em crianças com deglutição atípica. Braz. j. otorhinolaryngol. [serial on the Internet] 2012 Jan [cited 2016 Mar 29]; 78(1):120-5. Available from: http://www.scielo. br/pdf/bjorl/v78n1/v78n1a19.pdf.

26. Suliano AA, Rodrigues MJ, Caldas Júnior ADFC, Fonte PP, Porto-Carreiro CF. Prevalência de maloclusão e sua associação com alterações funcionais do sistema estomatognático entre escolares. Cad. Saúde Pública [serial on the Internet] 2007 Ago [cited 2017 Sep 15]; 23(8):1913-23. Available from: http://pesquisa.bvs. br/brasil/resource/es/lil-456025.

27. Blood GW, Blood IM. Victims seeking help from speech-language pathologists: bullying, preparedness, and perceptions. Folia phoniatr. logop. 2016;68(1):29-36.

28. Almeida KL, Cavalcante A, Silva JS. The importance of early identification of bullying: a review of the literature. Rev Pediatr. [serial on the Internet] 2008 Jan-Jun [cited 2017 Nov 27]; 9(1):8-16. Available from: http://www.conhecer.org.br/download/ BULLYING/LEITURA\%2011.pdf. 